Grigory Bondarenko

University of Ulster

Coleraine BT52 1SA, Northern Ireland

\title{
AUTOCHTHONS AND OTHERWORLDS IN CELTIC AND SLAVIC
}

\section{Introduction. Separation of Ireland in Mesca Ulad.}

When dealing with Irish Otherworld one encounters the problem of the beginning of historical consciousness in Ireland. The time immemorial when the Túatha Dé were said to have ruled Ireland as described in the first half of "The Wooing of Etaín" (Tochmarc Etaíne) is perceived as a period during which there is no sharp division between this world and the Otherworld, nor between sons of Míl and the Túatha Dé, the time when gods walked on earth (Bergin, Best 1934-38: 142-46). ${ }^{1}$ One can even argue that even in the later periods (according to Irish traditional chronology), as they are reflected in early Irish tradition, the border-line between this world and the "supernatural" existence is transparent and in any relevant early Irish narrative one can hardly trace a precise moment when a hero enters the "Otherworld". What is remarkable is that one can definitely detect "otherworldly" characters in this environment such as the supernatural beings (áes síde) that are associated with a particular locus, a síd. The seemingly "historical" question of when lower Otherworld in Ireland was first separated from the middle world of humans is dealt with in a number of early Irish tales. Let us focus on a short fragment from an Ulster cycle tale "The drunkenness of the Ulaid" (Mesca Ulad). The problem of áes síde and their opposition to humans is posed here only in order to determine the conflict in the tale. This question as such is not relevant to the Ulster cycle, though it may be taken as an important stimulus for many conflicts described in Early Irish literature. The fragment forms an introduction to a younger version of Mesca Ulad $\left(\mathrm{MU}^{2}\right)$ and is taken from the Book of Leinster 261b:

${ }^{1}$ Nevertheless even according to the first part of this tale the Túatha Dé are located in their underground residences (síde): Síd in Broga, Brí Leith, Cleitech etc. The feature shows strong association of the old pagan gods with burial mounds and the chthonic sphere in early Irish literature. 
Ō do-rīachtatar Meic Mīled Espāine Hērind tānic a ṅgáes timchell Tūathi Dé Danann. Cu ru lēiced Hériu ar raind Amairgin Glúnmáir meic Mĩled. Ūair is samlaid ro baī side rígfili 7 rígbrithem. Cu ru raind Hērinn dar dó 7 co tuc in leth ro boí sís d'Hērind do Thüaith Dé Danann et in leth aile do Maccaib Mìled Espāine da chorpfhini fadéin.

Do-chuatar Tüath Dé Danann i cnoccaib 7 sìdbrugib cu ra accallset sída fo thalmain dóib. Bar-fhácsat cúicfhiur díb ar comair cacha cóicid i nHērinn ic mórad chath 7 chongal 7 áig 7 urgaile etir Maccu Míled. Bar-ácsat cūiciur díb ar chomair cúicid Ulad int shainruth. Anmand in chúicfir sin, Brea mac Belgain a Drommannaib Breg, Redg Rotbél a Shlemnaib Maige Ítha, Tinnell mac Boclachtnai a Sléib Edlicon, Grici a Cruachán Aigli, Gulban Glass mac Gráci a Beind Gulbain Guirt meic Ungairb (Watson 1941: 1; LL 261b).

When the sons of Míl of Spain reached Ireland, their wisdom circumvented the Túatha Dé Danann. Ireland was left to the division of Amorgen Glúnmár, son of Míl, for he was a kingly poet and a kingly judge. He divided Ireland in two and gave the half under the ground to the Túatha Dé Danann and the other half to the sons of Míl of Spain to his own kin.

The Túatha Dé Danann went into the hills and fairy regions, and they dug the fairy-mounds (síde) underground for them. They left behind, for each fifth of Ireland, five of their number to increase battles and conflicts and strife and struggle among the sons of Míl. They left behind five of their number for the fifth of Ulaid in particular. The names of those five were Brea son of Belgan from the ridges of Brega, Redg Rotbél from the plains of Mag Îtha, Tinnell son of Boclachtnae from Slíab Edlicon, Grici from Cruachán Aigli, Gulban Glass son of Gráci from Bend Gulbain Guirt maicc Ungairb.

Leaving aside for the moment the pentadic symbolism of the fragment let us consider the opening lines of the narrative. The special localization of the Otherworld is associated in this text (as well as in other narratives to be discussed) with the coming of the sons of Míl and the beginning of Goidelic Ireland. It is not surprising that the very notion of the separation between the world of humans and the Otherworld is closely related to the beginning of history as such. When history begins the sacred (belonging to gods) has to be separated from the profane (belonging to mortals). One can argue that Ireland has experienced several "beginnings" of history, and alongside with the coming of Christianity and the Anglo-Norman invasion,

${ }^{2}$ V. 1. Redg, Radg Y; Ridhgell E. Rotbél, Rodbel YE, Boglacthna E. 
the coming of the sons of Míl is one of those beginnings of history in medieval Irish historiography. The coming of the sons of Míl has been interpreted by several scholars as the triumph of men over the elder gods. The latter phenomenon known also in Classical myths introduces not only history but also mythology as a system governing the relations between men and gods, profane and superhuman. This phenomenon of early Irish mythology was earlier commented upon by M.-L. Sjoestedt:

The day on which the race of men triumphed over the race of gods marks the end of the mythical period when the supernatural was undisputed master of the earth, and the beginning of a new period in which men and gods inhabit the earth together. From that moment the great problem of religion becomes important, the problem of relationship between man and the gods. The mythology states the circumstances in which the charter regulating this relationship was established once and for all (Sjoestedt 1949: 47). ${ }^{3}$

It is significant that the victory of the sons of Míl over the Túatha Dé Danann is associated with their wisdom, intelligence (gáes) rather than their military strength. The events alluded to in the tale are explored in Lebor Gabála Érenn ("The Book of the Conquest of Ireland") in the section devoted to the coming of the sons of Míl and their victory over the Túatha Dé Danann. The main driving force of Ireland's division in Mesca Ulad is the same Amorgen, who plays the most active role at the taking of Ireland by the sons of Míl. It should be remembered that the taking of Ireland by the sons of Míl is described as a contest between the druids and the wise men of the Túatha Dé against the druids and filid of the sons of Míl. The author of Lebor Gabála refers to such an early authority as Cín Dromma Snechta in stating that druids and filid of the sons of Míl destroyed the magic army conjured by the earth-goddess Ériu: they "sang spells to them, and they saw that they [the warriors] were only sods of the mountain peat" (conrochansat a ndruidh-seom 7 a filid dīchetla dōib, conaccater nī batir [acht] fhoid mōn na slēibe) (Macalister 1956: 36). When confronting "the wind of druids" (gāeth druad) on the sea the sons of Míl blame their learned men (āes dāna) for their failure, and it is only Amorgen who can confront the magic of the Túatha Dé with his spells (Macalister 1956: 38 , 114). Amorgen is also associated with divisions and judgments in Lebor Gabála but the divisions and judgments concern in this instance the sons of Míl and the only agreement between them and the Túatha Dé ever mentioned in Lebor Gabála is when Milesians form a marriage-alliance with the Túatha Dé Danann, giving them half of Ireland in return for their wives

${ }^{3}$ This refers also to a treaty between the Dagda and the sons of Míl mentioned in Hull 1933: 55-56.

${ }^{4}$ Note also earthly/telluric character of the Túatha Dé magic army. 
(Scowcroft 1988: 9). Amorgen tries to judge a dispute between Éremón and Éber when they defeat the Túatha Dé Danann and his judgment finally leads to Ireland's division in two parts, north and south, that is, Éremón's and Éber's (LL 1745-50, 1780). Amorgen is a knowledgeable poet and judge able to divide and govern the existence with his demiurgic functions. His name Amorgen is given to other powerful filid in the Irish literary tradition, it literally could probably mean 'song-born' (cf. amar 'song', DIL s.v., Kalygin 1997: 51, but according to Vendryes "né de la souffrance, fils du chagrin", LEIA A-65). Knowledge and magical abilities are the dominant factors that helped the sons of Míl to obtain Ireland, thus one should not attribute the second (military) Dumezilian function to them as opposed to the first priestly and sacred function of the Túatha Dé Danann.

The duality of Amorgen's division corresponds to the duality of Ireland's division into north and south, Leth Cuinn and Leth Moga. However, the division here is vertical as opposed to the horizontal divisions of Ireland in its pseudo-history. The Túatha Dé are, as it were, exiled into the lower world, the fact that causes further acts of vengeance on their part which often form the nuclei of the subsequent stories in the Ulster cycle. As it was natural for early Irish narratives describing the distant past, the narrative is structured on the basis of particular mythological schemes. Thus the dual structure of the island's division is recycled in the tale: I mean here the same dual structure or a binary opposition between north and south, Érémon and Éber, Conn and Mug Nuadat, Uí Neill and Eóganachta (Shkunaev 1991: 29-30). The opposition between the human world and the lower world, between top and bottom reflects on a cosmological level the spatial division, the latter being more important for early Irish politics and ideology. These intrinsic divisions in early Irish tradition might have lead to the reduction of the "three cosmic zones" (middle, celestial and infernal) of the Indo-European worldview to two zones (upper and lower) in Ireland (Scowcroft 1988: 40 n. 111).

\section{The problem of the síd.}

The famous phrase from late seventh century St. Patrick's life by Tírechan describing the inhabitants of the síd does not explicitly connect them with the Túatha Dé but implies their affinity to pagan gods: sed illos uiros side aut deorum terrenorum aut fantassiam estimauerunt ("but they thought they were men of the síde or of the earth-gods or a phantom') (Bieler 1979: 142). ${ }^{5}$ The phrase describes the reaction of the two

\footnotetext{
${ }^{5}$ According to K. Jackson side in Tírechán might mean 'fairies' in the gen. pl. and be glossed by Lat. aut deorum terrenorum accordingly (Sims-Williams 1990: 76 n. 6). deorum
} 
noble sisters when they see St. Patrick and his clerics. Latin terminology employed by Tírechan derives from Classical mytho-religious milieu and points to certain Roman connotations apparent for readers learned in Latin. Tírechán as an early Hiberno-Latin author was probably aware of the phenomenon of chthonic gods in Classical tradition and more specifically in ancient Roman religion. ${ }^{6}$ His explanation of áes síde here is based on a kind of interpretatio Romana where the inhabitants of the Irish underworld are equated with the elder chthonic or terrestrial gods of Roman religion. Roman chthonic gods presided over the world of the dead (Scheid 1998: 97) and this association may be supported by the Irish material, where síd is an ambiguous Otherworld quite often hostile to humans and sometimes associated with ancestors or the dead ones (cp. the episode with Fróech's burial in TBC under note 11). There are also archaeological associations which make relevant this link of the síde to the domain of the dead. As we know many síde or 'fairy mounds' of Ireland mentioned in the medieval literature are in fact Neolithic burial mounds (such as Newgrange, Knowth, Dowth etc.) Could there have been continuity in memory between the culture of the Boyne valley and later Goidelicspeaking population where the status of áes síde as gods presiding over the ancient burial grounds has been preserved?' ${ }^{7}$ The etymology of sid related to Welsh gorsedd 'manmade tumulus, natural hill' (Sims-Williams 1990: 64), Latin sedes 'seat, abode' and by extension, 'temple' and 'burial place' in later Latin, and to Greek $\check{\varepsilon} \delta o \varsigma$ (as in $\theta \varepsilon \hat{\varepsilon} v \ddot{\varepsilon} \delta o \varsigma$ ) with the meaning 'seat, abode, temple' implies the original meaning of the word as 'a residence [of the supernatural beings, earth-gods] (Maier 2004: 137-38; Meid 1970: 71-72; Markey, Mees 2003: 154; Koch, Carey 2003: 418, cf. also Ved. sadas-, devānām sadane 'in the seat of the gods' RV 8.13.2; West 2007: 123). ${ }^{8}$

terrenorum can also be interpreted as gen. partitivus.

${ }^{6}$ Lat. terrenus refers to infernal deities like Medea: terrena...numina ciuit Ovid, Met. 7.248. In the late Middle Irish Cóir Anmann ('Fitness of Names') the Dagda himself is called an 'earth-god' (día talmhan) (Arbuthnot 2007: 44). See also a discussion of the episode from Tírechan with an emphasis on the early Irish native roots of the phenomenon in Borsje 2009: 53-81.

${ }^{7}$ Koch argues in favour of ideological continuity between the Celtic-speaking Irish and the builders of the Boyne valley monuments, so that the image of áes side is seen as a recollection of the old theocracy (Koch 1991: 24). I am inclined to more religious rather than historically motivated explanation.

${ }^{8}$ According to Hamp etymologically distinct from síd 'peace' (Hamp 1982: 141). Burial associations of the sid are shown in the fragment from TBC (Rec. I), where Fróech slain by Cú Chulainn is taken by supernatural women into a mound called after him Síd Froích: Coínti a ndúnad n-uile Fróech. Co n-accatar banchuire i n-inaraib úanib for colainn Froích maic Idaid. F-a-cessat úadib issa síd. Síd Froích ainm in tshíde sin íarum. ('The whole camp bewails Fróech. They saw a band of women dressed in green tunics over the 
Thus the side being residences of the elder gods were supposed to have existed even before the exile of the "new gods", the Túatha Dé. ${ }^{9}$ Finally, the "hidden" chthonic gods seem to have been mentioned in early Irish poetry, when the dwarf Senbecc declares the source of his wisdom and knowledge. Senbecc (lit. 'A little old one') from the side was looking for magic nuts of knowledge at the source of the river Boyne at Segais in order to oppose Cú Chulainn's force by magic and music. Senbecc introduces himself to Cú Chulainn with a short poem:

Nidam mac, nidam fer, nidam ferdomhan,

fesa rom dánsattar dé díamra

Abhcánsa saoí fealbhais,

file a Seghais, Senbhecc mo ainm.

ua Ébhric a siodhaibh

I am not a boy, I am not a man, I am not a minor;

hidden gods have granted me knowledge.

I am a small dwarf, a sage of enchantment,

a fili from Segais, Senbecc is my name,

the grandson of Ébrec from the síde.

(Breatnach 1981: 60, Breatnach's translation is slightly amended).

The poem explicitly connects supernatural knowledge with the sid. It is very important that a protagonist here is non-human, and his knowledge also seem to lack human dimension. Senbecc's knowledge (fius) is granted by the old gods hidden underground, which implies that Senbecc is not one of the gods but belongs to a specific layer in the early Irish supernatural hierarchy somewhere close to leprechauns of the later folk tales. He is an anthropomorphic creature from the sid, the fact which shows a complex nature of the síd and its inhabitants. The dwarf calls himself a suí 'sage' associated with enchantment or charms (felmas, he is also a sai ecsidh 'sage of poesy' in BB $308 \mathrm{~b} 27)$. And he is also a fili 'poet, story-teller'. Judging from this archaic poem we can better understand connections and properties of the supernatural knowledge (fius, suithe) connected with the Otherworld and magical practices in the early Irish literature. A structurally similar phrase, which may support the reading of the cited poem, is uttered also by Cú Chulainn in response to Emer, his future wife, in time of their first encounter, Cú Chulainn boasts of being a great intel-

corpse of Fráech mac Idaid. They carried him off into the síd which was called Síd Fraích ever afterwards.') (O'Rahilly 1976: 27).

${ }^{9}$ Cf. also a binary opposition in Túatha Dee 7 Ande, LU 1344 'gods and chthonic gods' (not negative $a n$-, it would give in- in front of $d$-, rather from * ${ }_{0} d h e^{-}$, possibly under Brittonic influence) (Lambert 1979: 143-44). 
lectual to the same extent as a great warrior: conidam fissid fochmairc hi cerdaib dé druidechta ('And I am a wise man in studying the crafts of the gods of druidism/ gods of magic') (van Hamel 1978, 30). ${ }^{10}$

The nuances of the vocabulary employed in the fragment from $M U$ are not clear to a modern reader. There is definitely a difference intended between sídbruig and síd. As we mentioned síd is usually interpreted as 'fairy mound', or 'elf-mound', whereas sídbruig is sometimes invested with a more general meaning of 'fairy region' (Watson 1941: 101) or is explained as 'fairy mansion' (DIL, S 215.86). The second part of the compound here is a Middle Irish bruig (OI mruig) 'land, cultivated land, holding', thus a broader meaning 'fairy holding, fairy territory' is preferable. The most obvious illustration of the difference between síd and sídbruig is to be found in the nomenclature associated with the most famous sid in Ireland, Síd in Broga, the burial mound and the megalithic tomb now called Newgrange. The territory adjacent to - and including - the tumulus (síd) itself was known as Bruig na Bóinne, or Bruig Meicc ind Óc, or simply Bruig $^{11}$ (as the most famous of all brugai in Ireland) (Coffey 1912: 27). This territory consisted of several burial mounds and other man-made phenomena and was traditionally known as one of the primeval burial grounds in Ireland before the coming of Christian faith (primreilce Hêrend ría cretim) (LU 4068-4204). It is not only associated with the Túatha Dé Danann and other mythological creatures who have been buried there but it is also described as a burial ground of several legendary kings of Tara (Tuathal Techtmar, Fedelmed Rechtach, Conn Cétchathach etc.). It is noteworthy that the dindshenchas of Bruig na Bóinne mentions Síd in Broga as one of the monuments on site: the síd is said to have been built by the Dagda and is described as his fort (din, dún) (Gwynn 1906: 10-24; Stokes 1894: 292).

The phrase ra accallset sída fo thalmain dóib ('they dug the fairy mounds (side) underground for them') adds to the ambiguity of the semantics of the sid. It is possible that sida here refers not to the fairy mounds but to the inhabitants of the fairy mounds and is equivalent to áes síde. The separate usage of pl. síde as a term for the chthonic inhabitants is probably supported by Fiacc's hymn, composed in archaic language with an abnormal word order, where it is stated that before the coming of Christianity the people of Ireland 'worshipped the side' (tūatha adortais sìde) (Stokes, Strachan 1903: 317). ${ }^{12}$ The stress on the un-

${ }^{10}$ Compert Con Culainn an other stories, ed. by A.G. van Hamel (Dublin, 1978), p. 30.

${ }^{11}$ Cf. i n-airthiur in mbroga (LU 10591) with a survival of OIr. mruig.

${ }_{12}$ The reference though may equally be to the mounds and their inhabitants and can be translated: 'the peoples used to worship fairy-mounds' (Sims-Williams 1990: 76 n. 6). 
derground location of the síde (fo thalmain) is quite specific for $M U$ : it is sometimes specified in early Irish literature that the sid is located under the ground but this point is important here as the vertical division of Ireland between mortals and Túatha Dé is discussed earlier. The form $r a$ accallset here is also quite problematic: J. Carmichael Watson reads it as ro-pret. $3 \mathrm{pl}$. from the verb ad-gíalla 'serves, is in clientship to, gives hostages to, submits to' (DIL s.v. ad-gíalla; Watson 1941: 63). As suggested by the DIL, the form may also refer to ad-claid 'renders liable' if sida is acc. pl., which does not make a big difference in the meaning of the phrase. If one accepts the meaning 'to give hostages to' then the phrase ra accallset sída fo thalmain dóib can be translated as 'the síde under the ground granted hostages to them'. ${ }^{13}$ The following sentence starting Barfhácsat cúicfhiur díb could then refer to the autochthonous inhabitants of the síd (sída) rather than to the Túatha Dé Danann. On the other hand, as J. Carey suggested in a private communication, it is equally possible that the verb ad-claid is to be taken here in the meaning 'digs', so that it would refer to the Túatha Dé constructing their underground dwellings (one of the rare cases where this kind of supernatural construction is described in literature) (DIL A 44.16-17). There is another instance where the verb ad-claid is used in the sense of "constructing a mound, or a defense'. It is found in the Metrical Dindshenchas of Alend with regard to its mythological founders: acclaidset múr nAlinde 'they dug the rampart of Alend' (Gwynn 1906: 82).

In Cath Maige Tuired on the other hand we encounter a "mythological age" of pre-separation, when gods (Túatha Dé Danann) inhabit the middle world of humans and are referred to as 'men of Ireland' (fir Érenn). Their enemies, Fomoire, are called in the tale 'champions of the síd' (trénfiru ant sídho) (Gray 1982: 34). An archaic $7^{\text {th }}$-century poem on a legendary king of Leinster, Mess-Telmann, refers to his exploits in the "vales of Fomoire" located in the underworld and associated with the realm of the dead: Māl ad-rūalaid ìathu marb,/ macc sōer Sètnai,/ selaig srathu Fomoire/ fo doine domnaib ('A prince who entered the lands of the dead/ the noble son of Sétnae/ laid waste the vales of Fomoire/ under the worlds of humans') (Meyer 1914: 6; Koch, Carey 2003: 52). According to $M U$, the Túatha Dé Danann joined their predecessors in the lower world when defeated by the new invaders, the sons of Míl (Scowcroft 1995: 139-140). Moreover, it seems that the Túatha Dé have acquired a status of sovereigns over these chthonic creatures (Fomoire) in the sid. This picture is supported by the account of the division of the

${ }^{13}$ As in J. Carey's translation in Koch, Carey 2003: 106. 
fairy mounds among the princes of the Túatha Dé preserved in the tale De Gabáil in t-Shída (Hull 1933: 55-56). T. O'Rahilly argued that the distinction between the Túatha Dé and Fomoire is a thoroughly artificial and "learned" one, and that it was popularised, if not created, by the author of Cath Maige Tuired (O'Rahilly 1946: 483). More balanced approach is that of S. Shkunaev who once remarked that one should not oversimplify relations between the Túatha Dé and Fomoire as a constant conflict between two irreconcilable divine and demonic opponents. The phenomenon is better explained as a dialectic combination of self-supplementing forces in a single closed system (Shkunaev 1991: 20-21). These complex relations between the Túatha Dé and Fomoire allows the next tale we are going to discuss, Airne Fíngein, to describe the protagonists mentioned in our fragment from $M U$ as Fomoire left in Ireland after the Second Battle of Mag Tuired.

\section{Associated fragment from Airne Fíngein.}

The version of the story as preserved in $M U$ can be interpreted thus: after their exile underground the Túatha Dé have left in Ireland five of their number in each fifth of Ireland (twenty-five in total). Five of them have been left in the fifth of the Ulaid in particular. The significance of these pentads here is likely to be related to the notion of unity and integrity: the whole five fifths of Ireland are supervised by the pentads from the Túatha Dé. The "agents" of the Túatha Dé are left in Ireland in order to disturb the peace and stability of the new inhabitants, the sons of Míl. The acts of "sabotage" from the Túatha Dé after the coming of the sons of Míl are mentioned also in De Gabáil in t-Shída: ar collset Tūatha Dea ith ${ }_{\bar{a}}$ blicht im Maccu Mĩled ('for the Túatha Dé ('tribes of gods') destroyed grain and milk round about the sons of Míl') (Hull 1933: 55). The following description of the five characters from the Túatha Dé finds correspondence in another Old Irish tale Airne Fíngein where four of these five characters are described as the last remaining Fomoire in Ireland left behind after the battle of Mag Tuired. A woman from the side, Rothníam, relates to Fíngen the story of the four Fomóire.

Atā ann cethrar atrullaiset ré tūathaib Dé Danann a cath Muigi Tuired, co rrabatar fo dīchleith oc coll etha 7 älechta 7 mesa 7 āmurthoraid, .i. fer dīb i Slemnaib Maige Itha, Redg a ainm side; fer aile dīb i n-Dromannaib Breg, Brea a ainm sidhe; fer aile i Sléib Smóil, Greand a ainm side ; fer aile i críchaib Crūachan, Tinell a ainm side. Innocht ro sraīntea a hÉrinn arna tofund don Morrīgain ādo Bodb Síde Femin 
7 do Midir Bríg Léith 7 do Mac ind Óc, connābat foglaig Fomóire for Érinn cēin maras síl Cuind (Vendryes 1953: 14-16). ${ }^{14}$

There are four persons who escaped from the Túatha Dé Danann from the battle of Mag Tuired and they were hidden destroying corn, milk, mast, and sea produce, i.e. one man of them in the plains of Mag Itha, Redg his name, another man from them in the ridges of Brega, Brea his name, another man in Sliab Smóil, Greand his name, another man in the confines of Crúachu, Tinell his name. Tonight they were driven out of Ireland after being chased out by the Morrígan, and by Bodb of Síd Femen, and by Midir of Brí Léith, and by Mac ind Óc, so that there will not be plunderers from the Fomóire as long as the seed of Conn remains.

J. Carmichael Watson suggested that the fragment from $A F$ may derive some of its story from the earlier version in $M U$ and can hardly be independent evidence for the names (Watson 1941: 51). Nevertheless, the language of the fragment from $A F$ points to an Old Irish date, and a separate list of the four characters from the Túatha Dé Danann (Morrígan, Bodb, Midir, and Mac ind Óc) involved in the pursuit suggests a unique and independent account. Here, four, not five characters are associated

${ }^{14}$ v.l. ata ann, or an ben add. L; om. D. ann, and B. cethrar, ceathrar DL; ceithrar B. atrullaiset, atruluiseat D. ré, re LB; ria A. tūathaib, tuath- LAB. Dé Danann, dé .d. D; de do$\operatorname{nan} n$ A; de .d. an $n$ B; d.d. L. Muigi, muighi DL. Tuired, tuireth A; turedh L ; tuireadh D. co rrabatar, co rabutar $\mathrm{D}$; cu rabutar $\mathrm{L}$; cor rabatar $\mathrm{A}$. fo dichleith, om. $\mathrm{AB}$; fo dhicheltair L ; fo dicleth i n-Erinn D. oc coll, oc caill B ; ag coll L; oc mildeadh D. etha, eatha D. blechta, bleachta L; blecta B. 7 mesa 7 murthoraid, 7 mortoraidh 7 measa D. mesa, messa A. murthoraid, murrthar- A; murtarid B; mhurthor- L. i slemnaib, i s-slemnaib D ; a slemnaib A; a slemhnaibh L. Maige, mhuighi D; maigi A; muighi L. Itha, hitha DL. Redg, Redhg L; .i. redg AB. a ainm, ainm B. side, sidé A. fer, fear D. aile, om. AB; aili L; ii. D. dib, om. L. 3-4. quatuor uirorum ordo differt : Redg G-nu Brea Tinel AB ; Redg Brea Tinell Greand D ; Redg Brea G-nu Tinel L. i n-dromannaib, i ndromannuibh L ; a ndromannaib A; dronandaib B; i ndruimnib D. Breg, bregh D; breag L. Brea, bréa D; i. bréa A; .i. brea B. sidhe om. ABL. fer, fear D aile, om AB; aili L; ii. D ; dib add. AB. i sléib, i sleibh L; a sléib A ; a sleib D; i sleb B. Smóil, shmoil D; smoil LB. Greand, g-nu ABL. $a$ ainm, ainm B. side, sidhe D; sidé A; om. L. fer, fear B. aile, ii. D; aili L; dib add. AB. $i$ críchaib, a creacuibh L ; a crich- D; hi críchaib $\mathrm{AB}$. Crūachan, cruachna $\mathrm{AB}$; cruach- L. Tinell, tinel AB. side, sidhe D; sidé A; om. L. innocht, anocht D; indocht A; ar si add. D. ro sraintea, rosruitheá $\mathrm{A}$; rosruinthea $\mathrm{B}$; rosrueintea $\mathrm{L}$; roloingsighsedar D. a hÉrinn, a heir- L; a herind B. ar na tofund, om. ABL. don Morrīgain, i. in morrigan A ; i. in morigan B ; i. in morrighan L. 5-6. do, ter om. ABL. Bodb, badb AB. Síde Femin, a sidh ar femin D; sidhe fem- L. Midir, mid- B ; mig- A. Bríg, brí D ; br- L; brig AB. Léith, leith LAB. ind Óc, ind óg L ; in oicc D; ind oc B. connābat, connabeth A ; conabeid D. foglaig, foghlL ; foghlaighe D. Fomóire, fomóir A ; fomóri B ; fomhor- L ; ó fhodhmhoire D. for Erinn, i n-Erinn D; f- eir- L; for her- A; f- herind B. co brāth .i. add. A cu brath .i. add. A. cēin, cen AB. síl Cuind, cond D; sil cuind LB. 
with chthonic demons, the Fomóire, rather than with the exiled Túatha Dé Danann. The turning point of the plot in $A F$ is the second battle of Mag Tuired between the Túatha Dé and the Fomóire rather than the coming of the sons of Míl. There is definitely some kind of intertextual relations between the two fragments but the plots as well as the origins and roles of the heroes are different.

A closer look at the personal names and place-names may solve the enigma of the two plots in the stories. J. Carmichael Watson took Redg as a form of Redgach near Rámand in Donegal (co Rámaind is co Redgaig, Gwynn 1913: 258.32; Watson 1941: 51). Redg is also a noun meaning 'a sudden impulsive movement' (DIL s.v.) and here it is not necessary related to the place-name. It is more important that in both accounts the character is associated with the plain of Mag Itha situated along the river Finn near Raphoe in co. Donegal (Watson 1941: 128; Vendryes 1953: 51).

The eponym Brea in our fragments associated with the ridges of Brega is otherwise connected with Dún mBrea (modern Bray Head, co. Wicklow); it makes an appearance in both prose and metrical dindshenchas of Bend Étair. In this variant he is one of Partholón's people (another group of autochthons), and it is Partholón who sends him to the East (both characters from the dindshenchas and from the tales are located in the East of the country). Brea is said to be a "cultural hero": he is the first man who in Ireland built a house, made an iron cauldron and fought a duel (Gwynn 1913: 112; Stokes 1894: 330). His name seems to be related to bréo 'flame' which is often used to describe heroes and saints in complimentary sense (DIL s.v.) (cf. Lat. frigō 'to roast' and Scr. bhrjjáti 'to boil') (Kalygin 1997: 28). His name may be directly connected with his function as a cultural hero and the domesticator of the island. In another account from the dindshenchas (secundum quosdam) Brea is called one of the seven seers of Ireland and is also associated with Dún Brea in Uí Briuin Cúalann (LL 169b).

Sliab Smóil in Airne Fíngein and Slíab Edlicon in Mesca Ulad are likely to be one and the same mountain (Watson 1941: 1, 51). Slíab Smóil is variously called Slíab Smóil meic Eidlicon (Stokes 1900: 4531) and is identified as Slíab Bladma (modern Slieve Bloom, co. Laois) by Hogan (Hogan 1910 s.v. slíab smóil). According to DIL smál, smól, smúal 'ember, glowing coal, fire', and Slíab Smóil can be interpreted as 'Mountain of Embers'. Two different characters are associated with the mountain according to $A F$ and $M U$ : in $A F$ this is Greand (this name is likely to be equivalent with 1grend "beard, hair, bristles', DIL), and in MU this is Tinnell mac Boclachtnai. This Tinell is variously associated with the 'confines of Crúachu' (Síd Crúachan?) in Connacht according to $A F$. It is important that all these characters except for Redg are 
not located in Ulster and it does not support the $M U$ version of the story. The underground location of both Fomoire and áes síde discussed above resolves the problem of these two contradictory accounts in $M U$ and $A F$.

\section{The division of the síde of Ireland in De gabáil in $t$-sída.}

The third relevant Old Irish fragment is devoted to the division of the síde of Ireland among Túatha Dé and is found in the short tale De gabáil in $t$-sída (hereafter DGS, "Concerning the seizure of the fairy mound") from the Book of Leinster. Both Thurneysen and Hull agreed that the text from the Book of Leinster must be very archaic and composed at least as early as the ninth century (g.pl. dea for dia, the disyllabic oäc for óc, olse instead of ar se, imperative collá) (Thurneysen 1921: 604; Hull 1933: 54). An archaic character of the tale is supported by the absence of literary unity, fragmentary and unbalanced narrative, thereby revealing the compiler's deliberate intention to choose and focus on particular traditional points of attraction (both toponymic and semantic) (Shkunaev 1991: 21). Below I supply the text from the Book of Leinster (fo182rb41-182va15) with some variant readings from D.IV.2 (fo50rb25-50vab) and my translation:

Boí rí amra for Tūathaib Dēa i n-hĒre, Dagān a ainm. Ba mór, didiu, a chumachta, ced la Maccu Mīled ìar n-gabāil in tíre, a[i]r collset Tūatha Dēa ith $\bar{\emptyset}$ blicht im Maccu Mīled, con·digensat chairddes in Dagdai. Do.essart saide, iarum, ith 7ōblicht dóïb. Ba mór, di.diu, a chumachta-som in tan ba rí i tossuch, $\bar{\emptyset}$ ba hé fo-dāil inna sīde do fheraib Dea .i. Lug mac Cethnend i s-Síd Ro-Drubán ${ }^{15}$; Ogma i s-Síd Aircheltrai. Don Dagdu fessin, immurgu, Síth Leithet Lacht-maige, Oí a Síd ${ }^{16}$, Cnocc Báine, Brú Rūair. Síd in Broga, da·no, ba laiss i tossuch, amail as.berat.

Do-lluid, di·diu, in Mac Oäc cosin Dagda do chungid fheraind, ō fo-rodāil do chách. Ba dalta saide, di·diu, do Midir Breg Léith $\bar{\emptyset}$ do Nindid Fháith.

Ni-m·thá duit, - ol in Dagda, - Ni tharnaic fodail lemm.

Etá dam, di·diu, - ol in Macc Oöc, - cid bia co n-aidchi i-t' t[h]ri[u]b féin.

Do·breth dō-som ōn, īarum.

- Collá do-t' daim, - ol in Dagda,- ūaire do·romailt do ré[e].

Is menand, - olsé, - is lāa Ø adaig in bith uile, $\bar{\emptyset}$ iss ed ōn do·ratad dam-sa.

\footnotetext{
${ }^{15}$ Fodrubain, D IV 2.
}

16 Óo Cūalann, D IV 2. 
Luid, do·no, Dagán ass, īarum, 7 anaid in Mac Ooöc in-a s[h]íd. Amra, da·no, a tír hí-sin. A.taät tri chrand co torud and do.grés, 7 mucc bith-beō fo chossaib, 7 mucc fhonaithe, 7 lestar co l-lind sainemail, 7 ni-erchran and-sin uile do.grés.

There was a wonderful king over the Túatha Dé (Tribes of gods) in Ireland, Dagán by name. Great, then, was his power, even among the sons of Míl after the conquest of the country, for the Túatha Dé destroyed the corn and the milk of the sons of Míl until they made a treaty with the Dagda. Thereafter he saved corn and milk for them. Great, then, was his power, when he was king at first, and it was he who distributed the síde among the men of the gods, i.e. Lug son of Eithliu in Síd Rodrubán; Ogma in Síd Aircheltrai. To the Dagda himself, then, Síd Leithet Lacht-maige,..., Cnocc Báine, Brú Ruair. However, as they say, he had Síd in Broga at first. Then the Mac Óac came to the Dagda to ask for land when he has made division to everyone. He was a foster son of Midir of Brí Léith ('Hill of a Grey One') and of Nindid the prophet.

'I have nothing for you,' said the Dagda; 'I have not found (?) the share.'

'Get me then,' said the Mac Óac, 'that I will be in your own dwelling until night.'

That then was given to him.

'Go home,' said the Dagda, 'since you have used up your time.'

'It is clear,' said he, 'that the whole world is day and night, and it is that which has been given to me.'

Then Dagán went out of it, and the Mac Óac remains in his síd.

Wonderful, then, is this land. There are three trees with fruits always on them, and an undying pig at their disposal (lit. under feet), and a cooked pig, and a vessel with excellent drink, and all of this never decreases there.

A specific feature of this short tale is the name of the main protagonist, namely Dagán. This native name seems to be related to Gaulish Dagānia, $\operatorname{Dago}(n)$ 'good one' (Holder 1896: col. 1214, 1215) and is attested as a personal name in Early Ireland (DIL, s.v. Dagán). On the other hand, it was employed as a substitute for a Biblical name of a major northwest Semitic god Dagon in a famous Middle Irish Old Testament apocryphon Saltair na Rann (Stokes 1883: 5393, 5408, 5409). It is probable that the name of a major pagan Irish god in DGS was recontextualised in view of the Old Testament narrative, where Dagon is portrayed as a mighty pagan god of the Philistines (1 Samuel 5.2-7). It is also significant that the mythological 
character called Dagán is supplied in our text with the usual and more familiar epithet in Dagda (which is not a name but a title, 'The Good God', possibly replacing a tabooed name?) (Sjoestedt 1949: 38).

The destructive character of the Túatha Dé is described using the same lexis as in AF, cp. collset Tüatha Dēa ith 7 blicht im Maccu Mìled (DGS) and oc coll etha 7 blechta $(A F)$. Taking into account the earlier date of composition of $D G S$ and the composite character of $A F$, it is plausible to assume that the fragment on the destructive Fomoire in $A F$ is based on the account from the DGS involving destructive autochthons (Túatha Dé) and their confrontation with the Sons of Míl.

The tale invests the Dagda with all powers and responsibilities for the division of land after the conquest of the sons of Míl. Without question, he is limited to the lower world, that is side (fairy mounds). However the text is silent with regard to the decisive role played by Amorgen Glúnmár in the division of land according to $M U$. In contrast with the $M U$ account, the sons of Míl are portrayed here as silent victims of the old gods and especially of the Dagda. (Might it reflect the new Christian reading of the earlier myth, a reading which becomes evident in the word play with the Dagda's name (Dagán)?) The image of the all-mighty Dagda here is similar to his description in Tochmarc Étaíne (further TÉ) where he controls weather and harvest for Túatha Dé in the primordial time when gods walked on earth (conmidhedh na sina na toirthe doib) (Bergin and Best 1934-38: 142). The story of Oengus Mac ind Óc and his trick with time in the síd is also attested in $T E$. In contrast with the earlier variant of $D G S$, it is the Dagda himself who instructs Oengus how to get the síd from Elcmar, who is the owner the Bruig according to $T E$ (Bergin and Best 1934-38: 144, 146). I cannot agree with J. Koch who sees the Túatha Dé described in DGS as being subordinated by Milesians and that the 'treaty' (cairddes) in the tale is to be understood as referring to the division of Ireland by Amorgen (Koch 1991: 24). There is no reciprocity between the two sides in the tale; it is only the good will of the Dagda in his capacity as the god of harvest and prosperity that made possible the treaty ('peace', 'friendship'). ${ }^{17}$

The tale remains silent on the vertical division of Ireland between sons of Míl and Túatha Dé. The chronology reflected in DGS though seems to support the $M U$ mythologem: the side are distributed by the Dagda only after the 'treaty' (cairddes) with the sons of Míl is established and when the ancient inhabitants of the side have submitted to the exiled gods from Túatha Dé. It is significant that Midir is associated with Brí Leith but does

${ }_{17}$ The same is true about the treaty (kerenny $)$ made by Pwyll and Arawn, the king of Annwfn, in the first branch of the Mabinogi (Koch and Carey 2003: 412). 
not receive this abode from the Dagda. Most of the place names mentioned in the tale are obscure and cannot be associated with any known síde of Ireland (apart from Síd in Broga and Cnocc Báine, which can be possibly associated with the hill of Knockmany, co. Tyrone; $m$ here is probably due to a hypercorrect nasalization as in di cnuc mbane in G7 version of Scél Mongáin). ${ }^{18}$ In Brú Ruair which remains unidentified, brú stands either for bruig or for 3 brú 'brink, border' and is probably attached to the gen. of a personal name Ruar (Ó Riain, Ó Murchadha, Murray 2005: 208). Notwithstanding the authentic character of the place-names mentioned in the tale, - some of which could have easily been symbolic rather than geographical, as Síd Leithet Lachtmaige (Síd of the Width of the Milk-plain?), - the mythological space in the text is not continuous and is seen as a combination of several topographical objects (side) labelled with specific personal names (Lotman, Uspenskiy 1973: 288). The space in DGS has a "patchwork" character and the presence of a number of place-names makes the mythological space finite and countable, where most known sites (as Síd in Broga, Brí Leith (Ardagh Hill, co. Longford) and Cnocc Báine) served as mnemonic nodes which were important in various other narratives.

\section{Pro domo sua: an appendix on Northern Russian and Finno- Ugrian folklore.}

A phenomenon typologically similar to the early Irish topos of the Túatha Dé exile underground is observed in the northern Russian "synthetic history" and folklore dealing with the hidden supernatural autochthons (Chud' beloglazaya, чудь белоглазая). Чудь originally is an Old Russian ethnic name referring to the autochthonous Finnish population in Estonia, regions of Pskov and Novgorod, Karelia and Archangel region and is mentioned as early as in the twelfth century 'Tale of the past years' (Повбсть временныхъ лъъть): Въ Афетови же части сбодить русь, чюдь и вси языцб 'In the share of Japheth lies Rus', Chud' and all [other] nations' (Biblioteka 1997: §1; Cross and Sherbowitz-Wetzor 1953: 52). Old Russian чюдь (later чудь) is related to

${ }_{18}$ There is an inscribed stone circle (with the Neolithic zigzags and spiral ornaments similar in style to those found in Newgrange) and a Passage Grave on the hill. The monument belongs to the Boyne valley culture and in literary tradition said to have been the grave of a queen Báine ('Whiteness'?), the wife of Tuathal Teachtmhar and the mother of Feidlimid Rechtmar (LL 24a: Cnocc Báne), and by the peasantry of the $19^{\text {th }}$ century associated with the fairy Âine (MacNeill 2008: 307). Síd Chnuicc Báne also figures prominently in 'The story of Mongán' (Scél Mongáin), where a fili’s disciple visits the síd on Mongán’s behalf and finds hospitality from a noble couple who reside in the síd (LU 134a; N. White (ed.), Compert Mongáin and Three Other Early Mongán Tales (Maynooth, 2006), p. 169-70). 
Old Church Sl. тоуждь, штуждь, Russian чужой 'alien, foreign', and interpreted as an early borrowing from Germanic (Gothic piuda 'Volk', ON thjodh, OHG diota etc.) referring originally to the Germanic neighbours of the Slavs (Vasmer 1958: 352; Preobrazhensky 1949: 80) (on the other hand it is remarkable that Chud' is often associated with the Finno-Ugrian population rather than with Germanic). The form could have been contaminated by OCS/Old Russian чудо 'wonder, marvel'. There is also OCS штоудь(ъ) 'giant' which might be an equivalent of Old Russian чюдь, while in the later sources, чудь is described as supernatural giants (Chernykh 1999: 359; Komogortsev 2007: 273). The form's relation to OIr. túath is accidental though semantically it may also refer to marginal and alien "tribes" to the same extent as OIr. Túatha Dé. It is also important that on the level of historical narrative Chud' is always ethnically alien towards the Russians to the same extent as Túatha Dé are always alien towards the Irish (or the sons of Míl).

Later northern Russian folklore contains several accounts how Chud' were made to go into exile north-eastwards under an advance of Russian settlers. The last refuge which was open to them was to go underground and there are several tales describing how Chud'went underground (чудь под землю ушла) (Krinichnaya 1991: № 108-122). One should not associate the Chud' of Russian folklore with any Finnish autochthones in the North because the local Finnish autochthonic population Komi also have several legends concerning semi-supernatural autochthones called in Komi t'śud', an ethnic name borrowed from Russian (Komogortsev 2007: 273). Moreover, the Nenets population of the far North (Yamal peninsula) has similar legends involving the dwarfish autochthons called sirtya (sihirtya, sihirchi) who inhabited the tundra before the Nenets and later moved underground into the high sand hills (sede). After their settlement underground they hardly appear on the earth surface, and only Nenets shamans know the actual hills (sede) which are inhabited by sirtya (ibid. : 274; Lashuk 1968: 178-93). In the nineteenth century Russian explorers associated sirtya with Chud'. The most known account of the Chud's exile is known from the nineteenth century northern Russian folklore recorded by Maximov. The late date for the attestation of the mythologem is explained by the comparatively late ethnic and toponymic change in the area:

$<$...> чудь в землю ушла, под землей пропала, живьем закопалась. Сделала она это, по одним, оттого, что испугалась Ермака, по другим, оттого, что увидала белую березу, внезапно появившуюся и означавшую владычество Белого царя.

$<\ldots>$ Chud' went underground, was lost underground, buried themselves alive. They did as some people say, because they were afraid 
of Yermak, and as other people say, because they saw a white birch tree suddenly manifested and signifying the power of the White tsar (Krinichnaya 1991: № 108).

This motif of the underground escape/exile was interpreted as a reference to the ancient totemic creatures, submerging into earth, or mountain, or any water source in the end of their life (cp. Svyatogor's myth in Russian epic poems) (Krinichnaya 1991: № 110; Lashuk 1969: 213). I would rather connect this phenomenon of mythological consciousness with the specific attitude towards ancient autochthonous population. Non-Christian autochthones leave the historical scene as well as this world of humans and enter the lower Otherworld, which can be entered and accessed through caves, graves and mounds (ibid.: 209). To the same extent as Túatha Dé in Ireland, Chud' is associated with the burial mounds of the ancient autochthonous culture. It is also quite important that in Russian sources the earliest accounts of Chud' are associated with the pagan wisdom and are portrayed as persistent opponents of the Christian faith. The "Russian primary chronicle" is surprisingly eloquent in its entry under 1071 when giving a live ethnographic scene from the life of the Chud's shamans:

Приключися некоему новгородцю прити в Чудь, и приде к кудеснику, хотя волхвованья от него: он же по обычаю своему нача призывати бесы в храмину свою. Новгородцю же седящу на порозе тояже храмины, кудесник же лежаше оцепенев, и шибе им бес (Povest 1910: 146).

It happened that a certain man from Novgorod went among the Chuds, and approached a magician, desiring to have magic done by him. The latter according to his custom, began to call devils into his abode. The man from Novgorod sat upon the threshold of that house, while the magician lay there in trance, and the devil took possession of him (Cross and Sherbowitz- Wetzor 1953: 153).

The magicians from the Chud' are mentioned as late as the sixteenth century in the Stoglav (Hundred Chapters), the proceedings of the Church Council in Moscow in 1551. It tells about the magic of the Chudian arbuys (magicians) (Kozhanchikov 1863). Chud' is often portrayed as pagan autochthonic tribes seeking refuge from the coming of Christianity, and the last escape for them is found underground in the netherworld, where the "devils" of the Chuds' magician are located according to the Russian primary chronicle. They either hid themselves in the caves or bury themselves alive in low wooden houses (Lashuk 1969: 209). The ways of their underground exile are supported by the archaeological evidence from the Komi region which shows inhumation in small wooden houses (срубы) as the 
burial rite of local autochthones (чудь заволочская) (ibid. : 213). Ancient settlements, mounds and other burial sites are associated with Chud' on the rivers Pinega and Mezen (Mil'chik 1971: 15).

\section{Conclusion}

The separation of the lower Otherworld from the human middle world is explained as a 'historical' fact both in medieval Irish tales and in northern Russian folklore. The problem of subterraneous autochthones (áes síde or Chud') and their enmity towards humans is posed in order to determine the conflict in the narratives. The special localization of the Otherworld is associated in the texts discussed with the coming of the sons of Míl and the beginning of Goidelic Ireland or with the coming of Russian settlers and the beginning of history in the Russian North. The very notion of the separation between this world of humans and the Otherworld is closely related to the beginning of history as such. When history begins the sacred has to be separated from the profane (belonging to mortals). When this separation is performed the binary opposition between the lower Otherworld and the upper world of humans becomes a distinctive feature of the early Irish mythological narrative or Northern Russian and Komi folklore. Both Celtic and Slavic examples seem to reflect a transition stage when cosmological elements (such as the lower world, supernatural chthonic entities etc.) are superimposed on the emerging historical consciousness.

Abbreviations

LEIA: Lexique étymologique de l'irlandais ancien

LL: Book of Leinster

MU: Mesca Ulad

References

Arbuthnot, S. (ED.), 2007: Cóir Anmann: A Late Middle Irish Treatise on Personal Names (Part 2), Dublin: Irish Texts Society, Vol. 60.

Bergin, O. AND R. I. BEST (ED.), 1934-38: 'Tochmarc Étaíne', Ériu 12, 137-96.

BiвLIOTEKA 1997: The library of Old Russian literature, ed. by D. S. Lihachev, L. A. Dmitriev, A. A. Alekseev, N. V. Ponyrko, Saint Petersburg: Nauka (In 
Russian: Библиотека литературы Древней Руси / РАН. ИРЛИ; Под ред. Д. С. Лихачева, Л. А. Дмитриева, А. А. Алексеева, Н. В. Понырко, Т. 1: XI-XII века, СПб: Наука).

BIELER, L. (ED.), 1979: The Patrician texts in the Book of Armagh, Dublin: Dublin Institute for Advanced Studies.

BorsJe, J., 2009: 'Monotheistic to a Certain Extent. The 'Good Neighbours' of God in Ireland', in: Anne-Marie Korte \& Maaike de Haardt (eds), The Boundaries of Monotheism: Interdisciplinary Explorations into the Foundations of Western Monotheism, Studies in Theology and Religion 13. Leiden \& Boston: Brill, 53-82.

BreatnACH, L. (ED.), 1981: 'The Caldron of Poesy', Ériu 32, 45-94.

ChernYKh, P. YA., 1999: Historical and etymological dictionary of the modern Russian, vol. 1, Moscow: Russian language (In Russian: Историкоэтимологический словарь современного русского языка. T. 1, Москва: Русский язык.).

Coffey, G., 1912: New Grange (Brugh na Boinne) and other incised tumuli in Ireland, Dublin: Hodges, Figgis \& Co.

Cross, S. H. and O. P. Sherbowitz-Wetzor (ed.), 1953: The Russian Primary Chronicle. Laurentian Text, Cambridge, Mass.: The Medieval Academy of America.

GRAY, E. (ED.), 1982: Cath Maige Tuired, Naas: Irish Texts Society.

Gwynn, E. (ED.), 1906, 1913: The Metrical Dindshenchas, part II, III, Dublin, London: Hodges, Figgis; Williams \& Norgate.

van Hamel, A. G. (ED.), 1978: Compert Con Culainn an other stories, Dublin (Mediaeval and Modern Irish Series, vol. III).

Hamp, E., 1982: 'Varia X. Irish síd 'tumulus' and Irish síd 'peace”, ÉC 19, 141142.

Hogan, E., 1910: Onomasticon Goedelicum, Dublin: Hodges Figgis.

Holder, A., 1896: Alt-Celtischer Sprachschatz. 1 Band. Leipzig: B. G. Teubner.

Hull, V. (ED.), 1933: 'De gabáil in t-sída (Concerning the seizure of the fairy mound)', ZCP 19, 55-56.

Kalygin, V., 1997: The foundations of the early Irish mythopoetic tradition, Moscow: Russian Academy of Sciences, Institute for Linguistics (In Russian: Истоки древнеирландской мифопоэтической традиции, Москва: Российская Академия Наук, Институт языкознания.).

Kосн, J., 1991: 'Ériu, Alba, and Letha: When was a Language Ancestral to Gaelic First Spoken in Ireland?', Emania 9, 17-27.

Koch, J. T. and J. CARey (ED.), 2003: The Celtic Heroic Age. Literary Sources for Ancient Celtic Europe \& Early Ireland \& Wales, Aberystwyth; Oakville, CT: Celtic Studies Publications. 
Komogortsev, A., 2007: 'Tales of the 'underground people' and the cult of the 'pangolin crocodile' in Northern European Russia and the Urals', Volshebnaya Gora 13, 255-94 (In Russian: 'Предания о «подземном народе» и культ «ящера коркодела» на Севере Европейской части России и Приуралье', Волшебная гора 13).

KozhanchiKov, D. E. (ED.), 1863: Stoglav, Saint Petersburg: Imperial Academy of Sciences (In Russian: Стоглавъ, СПб: Типографія Императорской Академіи Наукъ).

Krinichnaya, N. A., 1991: Tales from the Russian North, Saint Petersburg: Nauka (In Russian: Предания Русского Севера, Санкт-Петербург: Наука).

LAmbert, P.-Y., 1979: 'La tablette gauliose de Chamalières', Études celtiques $16,141-69$.

LASHUK, L. P., 1969: 'Chud' in history and in legend', Voprosy istorii, 10, 208-218 (In Russian: 'Чудь историческая и чудь легендарная', Вопросы истории, 10).

LASHUK, L. P., 1968: 'Sirtya, ancient autochthones in Subarctic region', in Problems of anthropology and historical ethnography of Asia, Moscow: Nauka, 178193 (In Russian: '«Сиртя» - древние обитатели субарктики', in Проблемы антропологии и исторической этнографии Азии, Москва: Наука).

LEIA, 1959: Vendryes, Joseph, Lexique étymologique de l'irlandais ancien. A. Dublin : Dublin Institute for Advanced Studies.

Lotman, Yu. M. AND B. A. UspenskiY, 1973: 'Myth - name - culture', in Trudy po znakovym sistemam VI, Tartu: Tartu State University, 282-303 (In Russian: 'Миф - имя - культура', in Труды по знаковым системам VI, Тарту: Тартуский государственный университет).

Macalister, R. A. SteWARt (ED.), 1956: Lebor Gabála Érenn, part V, Dublin: Irish Texts Society.

MacNeILL, M., 2008: The Festival of Lughnasa, Dublin: Comhairle Bhéaloideas Éireann, University College Dublin.

MaIER, B., 2004: Der Religion der Kelten. Götter - Mythen - Weltbield, München: C. H. Beck.

Markey, T. and B. Mees, 2003: 'Prestino, patrimony and the Plinys', ZCP 53, $116-167$.

MeID, W. (ED.), 1970: Die Romanze von Froech und Findabair. Táin Bó Froích, Innsbruck: Institüt für Vergleichende Sprachwissenschaft der Universität Innsbruck.

MeYER, K., 1914: Über die älteste irische Dichtung: II. Rhythmische alliterierende reimlose Strophen, Berlin: Verlag der königl. Akademie der Wissenschaften.

MiL'снाK, M. I., 1971: Along the coasts of the Pinega and Mezen, Leningrad: Iskusstvo (In Russian: По берегам Пинеги и Мезени, Ленинград: Искусство). 
O`Rahilly, C., (ED.), 1976: Táin Bó Cúailnge Recension I, Dublin: Dublin Institute for Advanced Studies.

O’Rahilly, T., 1946: Early Irish History and Mythology, Dublin: Dublin Institute for Advanced Studies.

Ó Riain, P., D. Ó Murchadha, K. Murray (ED.), 2005: Historical Dictionary of Gaelic Placenames. Fascicle 2 (Names in B-), Dublin: Irish Texts Society.

Povest, 1910: The Russian Primary Chronicle. Laurentian Text, SaintPetersburg: Imperial archaeological commission (In Russian: Повесть временных лет по Лаврентьевскому списку, СПб: Императорская археологическая комиссия).

Preobrazhensky, A., 1949: Proceedings of the Institute of the Russian language, vol. 1, ed. by S.P. Obnorsky (A. Preobrazhensky, Etymological dictionary of the Russian language. The last fascicule (тело-ящур)), MoscowLeningrad: Institute of the Russian language, Academy of Sciences of the USSR (In Russian: Труды института русского языка. Т. І. Отв. ред. С.П. Обнорский (А. Преображенский, ‘Этимологический словарь русского языка'. Выпуск последний (тело-ящур)), Москва-Ленинград: Институт русского языка Академии наук СССР).

ScHeID, J., 1998: La religion des Romains, Paris: Armand Colin/S.E.J.E.R.

ScOWCroft, R. MARK, 1995: 'Abstract narrative in Ireland', Ériu 46, 121-158.

Scowcroft, R. MArk (ED.), 1988: 'Leabhar Gabhála. Part II: The Growth of the Tradition', Ériu 39, 1-66.

Shrunaev, S., 1991: 'Heroes and guardians of Irish tales', in: Tales and myths of medieval Ireland, ed. by S. Shkunaev, Moscow: Moscow State University Publishers, 5-30 (In Russian: 'Герои и хранители ирландских преданий', in Предания и мифы средневековой Ирландии. Пер. С. Шкунаева, Москва: Издательство МГУ).

Sims-Williams, P., 1990: 'Some Celtic Otherworld terms', in Celtic language, Celtic culture: a Festschrift for Eric P. Hamp, ed. by A. T. E. Matonis, D. F. Melia, Van Nuys, California: Ford \& Bailie, 57-81.

Sjoestedt, M.-L., 1949: Gods and heroes of the Celts, tr. by M. Dillon, London: Methuen.

STOKES, W. (ED.), 1900: 'Acallamh na Senórach', in Irische Texte mit Übersetzungen und Wörterbuch, 4th ser., Leipzig: Hirzel.

Stokes, W. (ED.), 1894: 'The Prose Tales from the Rennes Dindshenchas', $R C$ 15, 272-336.

STOKES, W. (ED.), 1883: The Saltair na rann: a collection of early middle Irish poems edited from MS. Rawlinson B 502, in the Bodleian Library, Oxford: Clarendon Press.

Stokes, W. And J. Strachan (ED.), 1903: Thesaurus Palaeohibernicus. A collection of Old-Irish glosses, scholia, prose and verse. Vol. II, Dublin: Dublin Institute for Advanced Studies. 
ThURNEYSEn, R., 1921: Die irische Helden- und Königsage bis zum siebzehnten fahrhundert, Halle: Niemeyer.

VASMER, M., 1958: Russisches etymologisches Wörterbuch. 3. Band, Heidelberg: Carl Winter.

Vendryes, J. (ED.), 1953: Airne Fíngein, Dublin (Mediaeval and Modern Irish Series, vol. XV).

Watson, J. Carmichael (ed.), 1941: Mesca Ulad, Dublin (Mediaeval and Modern Irish Series, vol. XIII).

WeST, M., 2007: Indo-European poetry and myth, Oxford: Oxford University Press.

\section{Domorodci i Drugi svjetovi u keltskome i slavenskom}

\section{Sažetak}

Nekolicina ranih irskih priča bavi se "povijesnim" pitanjem: kad se Podzemni svijet u Irskoj odvojio od gornjeg svijeta? Problem áes síde i njihovo neprijateljstvo s ljudima određuje sukob u pričama. Ovaj rad bavi se uvodnim dijelom priče iz Ulsterskog ciklusa, "Pijanstvo Ulata" (Mesca Ulad). Specijalna raspodjela Drugog svijeta u tekstu se povezuje s dolaskom Mílovih sinova i s početkom goidelske Irske. Sam pojam razdvajanja ovog ljudskog i Drugog svijeta usko je vezan uz početak same povijesti. Kad počinje povijest, mora se odvojiti sveto (koje pripada bogovima) od svjetovnog (koje pripada smrtnicima). Budući da se odvija razdvajanje, binarna opozicija između podzemnog, Drugog svijeta i gornjeg ljudskog svijeta postaje razlikovno obilježje ranih irskih mitova. Tipološki sličan fenomen uočen je i u sjevernoj ruskoj "sintetskoj povijesti" i folkloru koji se bave skrivenim natprirodnim starosjediocima (чудь белоглазая). I keltski i slavenski primjeri odražavaju prijelazno stanje u kojem se kozmološki elementi ugrađuju u rastuću svijest o povijesti.

Ključne riječi: Túatha Dé Danann, Irska, bogovi, síd, Drugi svijet, domorodci, staroirski, folklor, "sintetska povijest", Rusija

Key words: Túatha Dé Danann, Ireland, gods, síd, Otherworld, autochthons, Old Irish, folklore, "synthetic history", Russia 